\title{
The Protein Concentration in the Proximal Tubule of the $\operatorname{Dog} *$
}

\author{
John H. Dirks, $†$ James R. Clapp, $\ddagger$ and Robert W. Berliner \\ (From the Laboratory of Kidney and Electrolyte Metabolism, National Heart Institute, \\ Bethesda, Md.)
}

The mammalian proximal tubular fluid is generally considered to contain a low but definite protein concentration (1-3). The degree of glomerular capillary membrane permeability has been considered to range from that of a perfect ultrafilter to one yielding a protein concentration of $30 \mathrm{mg}$ per $100 \mathrm{ml}$ or more in the immediate filtrate. The most obvious evidence that protein is present in the glomerular filtrate is the presence of plasma proteins in the urine of normal man, dog, and rat. Estimates of the albumin in normal human urine, based upon a number of different methods, range from 15 to $31 \mathrm{mg}$ per 24 hours (4-8). This amount of albumin could easily be accounted for by a concentration less than $1 \mathrm{mg}$ per $100 \mathrm{ml}$ in the glomerular filtrate provided none was absorbed. The only direct estimate of protein in the mammalian nephron is to be found in the micropuncture studies of Walker, Bott, Oliver, and MacDowell (9). The protein concentration in 41 samples of glomerular and proximal tubular fluid from the guinea pig and the rat was found to range from less than $30 \mathrm{mg}$ per $100 \mathrm{ml}$ to less than $200 \mathrm{mg}$ per $100 \mathrm{ml}$. Earlier, Wearn and Richards (10) had found no protein in 11 frog glomerular samples and concluded that the glomerular filtrate was protein free.

The recent adaptation of micropuncture technique to the dog nephron by Clapp, Watson, and Berliner (11) made possible a direct estimation of protein concentration in the dog proximal tubule with a more sensitive method for the detection and identification of protein. The results indicate that the concentration of protein is approximately an order of magnitude lower than

\footnotetext{
* Submitted for publication October 14, 1963 ; accepted January 3, 1964.

$\dagger$ Medical research fellow, Medical Research Council of Canada.

$\ddagger$ Present address: Duke University Medical Center, Department of Internal Medicine, Durham, N. C.
}

estimated from previous micropuncture studies (9).

\section{Methods}

Studies were performed on five male or female dogs weighing 10 to $15 \mathrm{~kg}$. The dogs were anesthetized with $200 \mathrm{mg}$ Pentothal Sodium [sodium 5-ethyl-5-(1-methylbutyl)-2-thiobarbiturate] administered as a $2.5 \%$ solution in distilled water. Supplemental Pentothal was given during the experiment as necessary. The left kidney was exposed through a flank incision, and indwelling catheters were inserted into the ureter of the experimental kidney, the foreleg vein, and the femoral vein. Methods for exposing and supporting the kidney for micropuncture as well as for the tubular fluid collection and identification of the puncture site have previous!y been reported (11). In the present experiments, collections were continued to obtain a volume as near as possible to $0.25 \mu 1$. Samples in which red blood cells or obvious sediment could be detected on microscopic examination were discarded.

In all experiments, 15-minute periods for determination of inulin clearance were obtained while tubular fluid samples were being collected. After appropriate priming and sustaining infusion of inulin had been given, 30 minutes was allowed to elapse before collections were begun to insure adequate equilibration. Venous blood was drawn at the mid-point of each period, and urine was collected through a ureteral catheter. It previously has been demonstrated that the surgical manipulation necessary for tubular fluid collections does not appreciably alter the function of the experimental kidney when it is compared to its contralateral control (11). Tubular fluid inulin concentration was not measured in these experiments.

Albumin and gamma globulin in the tubular fluid were estimated by modifying the agar gel diffusion precipitin technique of Soothill (12). A phosphate buffer consisting of $0.15 \mathrm{M} \mathrm{Na}_{2} \mathrm{HPO}_{4}$ and $0.15 \mathrm{M} \mathrm{NaH}_{2} \mathrm{PO}_{4}$ in a $4 / 1$ ratio was mixed with an equal volume of normal saline and adjusted to $\mathrm{pH} 7.6$ with $0.1 \mathrm{~N} \mathrm{NaOH}$. A 2 g per $100 \mathrm{ml}$ solution of Difco Special Agar-Noble ${ }^{1}$ in the saline phosphate buffer was heated for 2 hours and then filtered through boiled filter paper under suction. Sodium azide, $0.01 \mathrm{~g}$ per $100 \mathrm{ml}$, was added to the original solution to prevent bacterial contamination. The fi'tered

\footnotetext{
1 Difco Laboratories, Detroit, Mich.
} 
agar was divided into 5- to $10-\mathrm{ml}$ portions and stored at $4^{\circ} \mathrm{C}$. Agar was heated, and $1.1 \mathrm{ml}$ was layered onto a $25-\times 75-\mathrm{mm}$ microscope slide resting on a level surface. This volume of agar resulted in a gel thickness of .55 $\mathrm{mm}$. Several such slides were made for each experiment. A special cutter was designed with 6 holes in a hexagonal pattern, with each hole one-hole diameter ( 0.030 inch) away from those adjacent to it and from a central hole of equal size. Five such patterns were cut on each microscope slide and the plugs removed by applying suction to a Pasteur pipette. The volume of the hole in the agar was $0.25 \mu \mathrm{l}$. The slides were stored in humidified Petri dishes until used.

A series of standards of dog albumin (Fraction V, $>95 \%$ albumin ${ }^{2}$ ) and gamma globulin (Fraction II, $>98 \%$ gamma globulin ${ }^{2}$ ) were set up. Standards, made up in isotonic $\mathrm{NaCl}$ solution, included the following concentrations in milligrams per 100 milliliters: all concentrations from 1 to 10 as well as $15,20,25,50$, and 100 .

Specific rabbit antisera to dog albumin and gamma globulin were prepared ${ }^{3}$ against purified antigens. A single line on agar gel diffusion and immunoelectrophoresis confirmed the purity of each antiserum. Dilutions of antisera used were $1 / 1,1 / 5,1 / 10$ for albumin and $1 / 4$, $1 / 11,1 / 20$ for gamma globulin.

Special $0.25-\mu 1$ pipettes were constructed, and this volume of the various standards was placed in succeeding central holes. The three antialbumin and antigamma dilutions were placed in the 3 holes to the right and left of the center hole, respectively. Tubular fluid samples were similarly taken up under oil, allowed to fill the 0.25- $\mu$ l pipette, and then blown into the center hole of the agar plate; the same dilutions of antisera were placed against it. If the tubular fluid sample was less than 0.25 $\mu 1$, the sample was measured with a cathetometer and the volume calculated. The pipette was then filled to 0.25 $\mu 1$ with isotonic saline solution to insure equal volumes of fluid in the center hole.

Slides were next placed in Petri dishes; the slides rested on moistened filter paper to prevent drying of the gel. Immunodiffusion was allowed to take place for 16 hours. The slides were then immersed in normal saline for 24 hours to remove unprecipitated protein, covered with moistened filter paper, and dried at $40^{\circ} \mathrm{C}$ until a thin film covered the slides. The slides were immersed in amido black stain for 2 hours and then rinsed with $2 \%$ acetic acid for 2 hours. The pattern of precipitin lines for the tubular fluid albumin and gamma globulin antisera complexes was compared with the pattern obtained with the various standards, and the closest visual correspondence to a standard was then designated as the tubular fluid protein concentration. The lowest albumin standard that gave a precipitate was $2 \mathrm{mg}$ per $100 \mathrm{ml}$; this volume contained $0.008 \mu \mathrm{g}$ of albumin. This result with the albumin standard was consistently reproducible. The gamma globulin standard had a lower limit of detectability at $5 \mathrm{mg}$ per $100 \mathrm{ml}$, and therefore the method

2 Pentex, Inc., Kankakee, II1.

3 By Dr. J. Hardwicke. was less satisfactory for detection of gamma globulin. The matching tubular fluid concentration was multiplied by the dilution factor needed to bring it up to a volume of $0.25 \mu 1$.

Protein concentration in urine collected during the periods of the first and last tubular sample collection was similarly quantified, undiluted and in dilutions of $1 / 10$ and $1 / 20$. The lowest dilution that gave a visible precipitin line was matched to a standard, and the protein concentration was then considered equal to this value multiplied by the dilution factor.

Serum albumin was determined by the HABA dye method of Rutstein, Ingenito, and Reynolds (13) as modi-

TABLE I

Protein content of tubular samples

\begin{tabular}{|c|c|c|c|}
\hline Dog & $\begin{array}{l}\text { Tubular } \\
\text { fluid } \\
\text { albumin }\end{array}$ & $\begin{array}{l}\text { Site of } \\
\text { puncture } \\
\text { as \% } \\
\text { proximal } \\
\text { tubule }\end{array}$ & $\begin{array}{c}\text { Tubular fluid } \\
\gamma \text {-globulin }\end{array}$ \\
\hline & $\mathrm{mg} / 100 \mathrm{ml} *$ & & $m g / 100 m l \dagger$ \\
\hline \multirow[t]{6}{*}{1} & $<2.8 \ddagger$ & $\begin{array}{c}\text { ? } 40-50 \\
35\end{array}$ & $\begin{array}{l}\text { (All undetectable } \\
\text { unless otherwise } \\
\text { indicated) }\end{array}$ \\
\hline & 4.0 & 45 & \\
\hline & 3.0 & 60 & \\
\hline & $<2.6 \ddagger$ & 15 & \\
\hline & $5.2 \ddagger$ & 40 & \\
\hline & 10.0 & 50 & 10 \\
\hline \multirow[t]{10}{*}{2} & $<2.0$ & & \\
\hline & $<2.7 \ddagger$ & 40 & \\
\hline & $<2.4 \ddagger$ & 45 & \\
\hline & 8.0 & 50 & \\
\hline & 6.0 & 20 & \\
\hline & $<2.3 \ddagger$ & 55 & \\
\hline & 6.0 & ? 25 & \\
\hline & $<2.7 \ddagger$ & $30-40$ & \\
\hline & 4.0 & 25 & \\
\hline & $3.7 \ddagger$ & 40 & \\
\hline \multirow[t]{6}{*}{3} & $5.4 \ddagger$ & $15-20$ & \\
\hline & 7.0 & $45-50$ & \\
\hline & $<3.1$ & $45-50$ & \\
\hline & 15.0 & 40 & 15 \\
\hline & 8.0 & 25 & \\
\hline & 5.0 & 30 & \\
\hline \multirow[t]{9}{*}{4} & $<3.5 \ddagger$ & 12 & \\
\hline & $<6.9 \ddagger$ & Early & \\
\hline & $<2.0$ & 28 & \\
\hline & $<2.0$ & 20 & \\
\hline & $<2.0$ & ? Late & \\
\hline & $<2.0$ & 20 & \\
\hline & $5.3 \ddagger$ & 28 & \\
\hline & 4.0 & ? 25-30 & \\
\hline & $<5.0_{+}^{+}$ & 50 & \\
\hline \multirow[t]{6}{*}{5} & $<2.0 \ddagger$ & $55-60$ & \\
\hline & 2.0 & 55 & \\
\hline & $<2.0$ & 40 & \\
\hline & $<2.0$ & $? 60$ & \\
\hline & 4.0 & 50 & \\
\hline & 6.0 & 20 & \\
\hline
\end{tabular}

* Lower limit of detection of albumin, $2 \mathrm{mg}$ per $100 \mathrm{ml}$.
+ Lower limit of detection of $\gamma$-globulin, $5 \mathrm{mg}$ per $100 \mathrm{ml}$. All full Lower limit of detection of $\gamma$-globulin, $5 \mathrm{mg}$ per $100 \mathrm{ml}$. All full $17.2 \mathrm{mg}$ per $100 \mathrm{ml}$.

i Sample $<0.25 \mu$ ld diluted with saline to bring to volume. Reading is multiplied by dilution factor. 
fied by Baxter using dog albumin as the standard and read on a Coleman spectrophotometer at $480 \mathrm{~m} \mu$. Plasma albumin was estimated at the beginning and end of an experiment.

Three tubular fluid samples were analyzed for albumin by a quantitative hemagglutination inhibition test (15). A lower limit of $0.012 \mu \mathrm{g}$ of albumin was detectable. ${ }^{4}$

After each micropuncture collection, the tubule was filled with latex and, after maceration in $50 \% \mathrm{HCl}$, microdissected as previously described (11); the distance of the puncture site from the glomerulus, as a fraction of proximal tubular length, was determined.

\section{Results}

The results of 38 proximal tubule collections from five dogs are shown in Table I. The tubular fluid concentration in each sample is indicated along with the location of the puncture site in the proximal tubule. Twenty-two samples were full $0.25-\mu 1$ collections. The other 16 were diluted between 1.08 and 3.44 times to bring them to equal volumes. The lowest albumin standard giving a precipitin line was $2 \mathrm{mg}$ per $100 \mathrm{ml}$. Therefore, any collected sample that gave no precipitin line is recorded as containing less than $2 \mathrm{mg}$ per $100 \mathrm{ml}$ multiplied by the corresponding dilution factor, if any. There were 18 such samples that contained less than 2 to $6.9 \mathrm{mg}$ per $100 \mathrm{ml}$, the majority being listed as less than $3 \mathrm{mg}$ per 100 $\mathrm{ml}$ albumin. Eighteen samples gave a precipitin line reading in the range of 2 to $8 \mathrm{mg}$ per $100 \mathrm{ml}$. Only 2 collections, at 100 and $15 \mathrm{mg}$ per $100 \mathrm{ml}$, respectively, exceeded this range. These were also the only 2 samples that gave a precipitin line

${ }^{4}$ Dr. Stewart Sell carried out these determinations.
DOG PROXIMAL TUBULE ALBUMIN CONCENTRATION

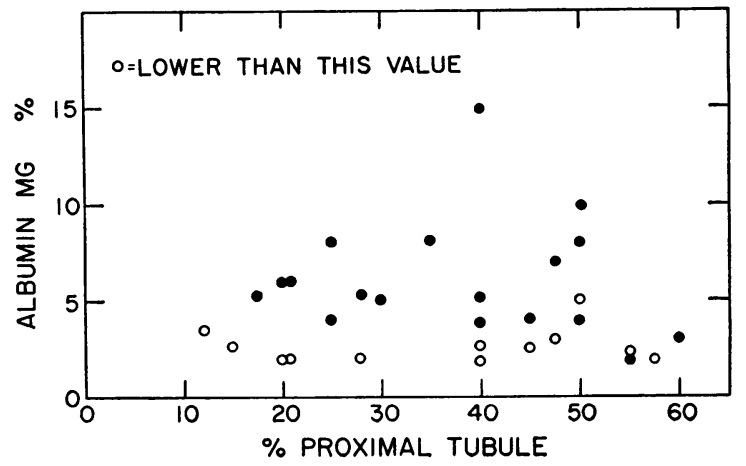

Fig. 1. Plot of the proximal tubular fluid albuMIN CONCENTRATION AS A FUNCTION OF THE POSITION IN THE PROXIMAL TUBULE FROM WHICH THE SAMPLE WAS COLLECTED.

with the gamma globulin antisera (also at 10 and $15 \mathrm{mg}$ per $100 \mathrm{ml}$ ). The possibility of some extracellular fluid contamination of these 2 samples exists. None of the other 36 samples gave a precipitin line with the antigamma globulin that gave a lower limit of detection at $5 \mathrm{mg}$ per $100 \mathrm{ml}$. All 22 full samples contained less than $5 \mathrm{mg}$ per $100 \mathrm{ml}$ gamma globulin, whereas the 16 "diluted" samples could be stated to contain less than 5.4 to $17.2 \mathrm{mg}$ per $100 \mathrm{ml}$.

Figure 1 shows a plot of the proximal tubular fluid albumin concentration as a function of the position in the proximal tubule from which the sample was collected. No particular pattern of change in concentration along the length of the accessible portion of the tubule is evident.

Table II displays the pertinent renal parameters studied for the left kidney in the five dogs. The

TABLE II

Renal function and urine protein content during tubular collections

\begin{tabular}{|c|c|c|c|c|c|c|}
\hline Dog & Weight & $\begin{array}{c}\text { Left } \\
\text { kidney } \\
\text { GFR* }\end{array}$ & $\begin{array}{l}\text { Urine } \\
\text { flow }\end{array}$ & $\begin{array}{c}\text { Plasma } \\
\text { albumin }\end{array}$ & $\begin{array}{l}\text { Urine } \\
\text { albumin }\end{array}$ & $\underset{\gamma \text {-globulin }}{\text { Urine }}$ \\
\hline \multirow{3}{*}{1} & $k g$ & $m l / \min$ & $\mathrm{ml} / \mathrm{min}$ & $\mathrm{g} / 100 \mathrm{ml}$ & $\mathrm{mg} / 100 \mathrm{ml}$ & $\mathrm{mg} / 100 \mathrm{ml}$ \\
\hline & 13.2 & 35.2 & 0.12 & 2.46 & 110 & $50-100$ \\
\hline & & 29.4 & 0.11 & 2.44 & 110 & 100 \\
\hline \multirow[t]{2}{*}{2} & 12.1 & 30.9 & 0.15 & 2.56 & 45 & 10 \\
\hline & & 24.6 & 0.16 & 2.56 & 30 & 10 \\
\hline \multirow[t]{2}{*}{3} & 14.2 & 24.2 & 0.26 & 2.80 & 60 & 50 \\
\hline & & 27.6 & 0.15 & 2.95 & 90 & 50 \\
\hline \multirow[t]{2}{*}{4} & 10.9 & 19.5 & 0.04 & 2.40 & 40 & 20 \\
\hline & & 18.7 & 0.05 & 2.37 & 30 & 20 \\
\hline \multirow[t]{2}{*}{5} & 15.1 & 39.0 & 0.4 & 1.90 & 6.0 & 5 \\
\hline & & 41.5 & 0.4 & 1.83 & 5.0 & 5 \\
\hline
\end{tabular}

* GFR = glomerular filtration rate. 
glomerular filtration tate ranged from 18.7 to 41.5 $\mathrm{ml}$ per minute in dogs weighing 10.9 to $15.1 \mathrm{~kg}$. Plasma albumin ranged from 1.83 to $2.95 \mathrm{~g}$ per $100 \mathrm{ml}$. Urine albumin varied between 5 and $110 \mathrm{mg}$ per $100 \mathrm{ml}$, and urine gamma globulin, between 5 and $100 \mathrm{mg}$ per $100 \mathrm{ml}$.

Three full samples were analyzed by the quantitative hemagglutination inhibition test. The lower limit of albumin detection was $0.012 \mu \mathrm{g}$ or 4.8 $\mathrm{mg}$ per $100 \mathrm{ml}$. The protein content of 1 sample was between 4.8 and $8 \mathrm{mg}$ per $100 \mathrm{ml}$. The other 2 contained less than $4.8 \mathrm{mg}$ per $100 \mathrm{ml}$. Two saline controls gave no inhibition. These few measurements thus gave results of the same order as found by the agar gel immunodiffusion technique.

\section{Discussion}

The accurate measurement of minute concentrations of specific proteins in submicroliter volumes of body fluids is still a formidable problem. It is generally agreed that immunochemical methods are the most specific but are difficult to quantify. Among current immunochemical quantitative approaches are the gel diffusion precipitin technique (12), the complement fixation method (16), the hemagglutination inhibition technique (15), and the blocking effects of albumin and the binding of $\mathrm{I}^{131}$ albumin by rabbit antialbumin (17). The gel diffusion precipitin technique of Ouchterlony (18) has been modified by Gell (19) for quantitative study of the small gamma globulin concentration of hypogammaglobulinemic states (20). More recently Soothill (12) has further adapted this method to the measurement of several proteins, including albumin, in the blood and urine. Blainey, Brewer, Hardwicke, and Soothill (21) have used this method extensively in the study of relative protein clearances in the nephrotic syndrome due to membraneous and proliferative glomerulonephritis. This method has also been applied to exercise and postural proteinuria $(22,23)$. The basic simplicity of the gel diffusion precipitin method lends itself to ready application to micropuncture experiments in the dog. Also, at the time of these experiments, this method seemed the most proved in quantitative immunochemical studies. It appeared easiest to differentiate subtle differences in the standards below $10 \mathrm{mg}$ per $100 \mathrm{ml}$, the range into which most tubular fluid protein concentrations fall. In this range, a given protein concentration can be estimated to $\pm 1 \mathrm{mg}$ per $100 \mathrm{ml}$. Despite the subjective element in the method, repeat independent visual matchings were in virtual agreement. Soothill (12) states that there is a coefficient of variation of $18 \%$ for albumin determinations; although the variability was not systematically examined in these studies, we believe it was not greater than that given by Soothill.

Our studies, based on this gel diffusion technique, indicate that the protein concentration in the dog's proximal tubule is lower than had been inferred from previous micropuncture study in mammals (9). In 18 samples, no albumin could be detected. In 14 of these a concentration of 3 $\mathrm{mg}$ per $100 \mathrm{ml}$ should have been detected; in 3 of the other 4 , the concentration detectable was $5 \mathrm{mg}$ per $100 \mathrm{ml}$ or less. In the 20 samples that yielded precipitin lines, the concentration averaged $5.9 \mathrm{mg}$ per $100 \mathrm{ml}$, and in only 2 samples was the concentration $10 \mathrm{mg}$ per $100 \mathrm{ml}$ or more. Gamma globulin was detected in only the latter 2 instances and generally appears to be present in smaller amounts than albumin in the proximal tubular fluid. Some confirmation of the validity of the measures of tubular fluid albumin by the gel diffusion technique may be derived from the similar results obtained with the hemagglutination inhibition technique (15) tested on 3 samples.

Most discussions on renal protein handling have been based on an estimated concentration of 30 $\mathrm{mg}$ per $100 \mathrm{ml}$ in glomerular filtrate. This figure is derived from the only other direct evaluation in mammals, by Walker and his co-workers (9), in micropuncture studies in rats and guinea pigs. They estimated tubular fluid total protein content by direct inspection of the flocculation occurring in a capillary tube treated with trichloroacetic acid and compared to various dilutions of normal plasma ; the normal plasma was assumed to contain $7 \%$ protein. Of 25 negative samples 8 were considered to contain less than $30 \mathrm{mg}$ per $100 \mathrm{ml}$ and 16 less than $80 \mathrm{mg}$. Sixteen collections were positive with 14 listed as less than $200 \mathrm{mg}$ per $100 \mathrm{ml}$ and 9 as less than $80 \mathrm{mg}$. This placed the possible range of tubular fluid protein concentration as extending from 0 to over $200 \mathrm{mg}$ per $100 \mathrm{ml}$. These results exclude the possibility of 
the glomerular capillary being grossly porous to plasma proteins, but the ultrafiltrate was considered to contain small, undefined amounts of protein. Wearn and Richards (10) made direct assessments of proximal tubular fluid protein in amphibians by the acetic acid-potassium ferrocyanide precipitate test. They obtained no precipitate in 11 samples. The lower limit of sensitivity of the technique of Wearn and Richards is not stated. Among indirect estimates are the 15 to $22 \mathrm{mg}$ per $100 \mathrm{ml}$ of protein obtained in the urine by Dock (24) by perfusing rabbit kidneys with cold serum to inhibit tubular function. Sellers, Griggs, Marmorston, and Goodman (25) calculated proximal tubular albumin concentration to be $7.6 \mathrm{mg}$ per $100 \mathrm{ml}$ by measuring the amount of dye-labeled albumin present in histological sections of the proximal tubule.

The glomerular basement membrane seems to be the major restriction to the passage of proteins into the filtrate (26). On the basis of this study, insignificant amounts of albumin cross the normal glomerular barrier. It is not possible to calculate a mean albumin concentration in the proximal tubule because of the large proportion of samples containing no detectable protein. Therefore, to speculate on the amount and nature of proximal tubular albumin reabsorption does not seem wise. In any case, a tubular albumin concentration of less than $1 \mathrm{mg}$ per $100 \mathrm{ml}$ would easily account for all albumin excreted.

\section{Summary}

1. Albumin and gamma globulin concentrations have been estimated in 38 samples of proximal tubular fluid from five dogs by a quantitative gel diffusion precipitin technique.

2. Eighteen samples had albumin concentrations in the range of 2 to $8 \mathrm{mg}$ per $100 \mathrm{ml}$. Another 18 samples had no detectable precipitin level and were therefore less than 2 to $6.9 \mathrm{mg}$ per $100 \mathrm{ml}$. Two samples had 10 and $15 \mathrm{mg}$ per $100 \mathrm{ml}$ of both albumin and gamma globulin. All other samples gave no gamma globulin precipitin line.

3. Three samples tested by the hemagglutination inhibition technique had albumin concentrations in the same range as above.

4. Albumin concentration did not change according to any pattern when plotted as a function of distance along the tubule.

\section{Acknowledgments}

The authors are grateful to Dr. J. Hardwicke, Birmingham, England, who prepared the antisera and aided in the methodology and in the initiation of these studies. We also thank Dr. Stewart Sell, National Institute of Allergy and Infectious Diseases, for the hemagglutination inhibition determinations and Miss Nordica Green for her capable assistance.

\section{References}

1. Smith, Homer. The Kidney. Structure and Function in Health and Disease. New York, Oxford University Press, 1951.

2. Squire, J. R., J. Hardwicke, and J. F. Soothill. Proteinuria in Renal Disease, D. A. K. Black, Ed. Oxford, Blackwell Scientific Publications, 1962.

3. Pitts, R. F. Physiology of the Kidney and Body Fluids. Chicago, Year Book Medical Publishers, 1963.

4. Rigas, D. A., and C. G. Heller. The amount and nature of urinary proteins in normal human subjects. J. clin. Invest. 1951, 30, 853.

5. Webb, T., B. Rose, and A. H. Sehon. Biocolloids in normal human urine. I. Amount and electrophoretic characteristics. Canad. J. Biochem. 1958, 36, 1159.

6. Berggard, I., and C. Risinger. Quantitative immunochemical determination of albumin in normal human urine. Acta Soc. Med. upsalien. 1961, 66, 217.

7. Boyce, W. H., F. K. Garvey, and C. M. Norfleet, $\mathrm{Jr}$. Proteins and other biocolloids of urine in health and in calculous disease. I. Electrophoretic studies at $\mathrm{pH} 4.5$ and 8.6 of those components soluble in molar sodium chloride. J. clin. Invest. 1954, 33, 1287.

8. Glass, R. H., C. Risinger, L. Wide, and C. A. Gemzell. Quantitative determination of albumin in normal urine by an immunochemical method. Scand. J. clin. Lab. Invest. 1963, 15, 266.

9. Walker, A. M., P. A. Bott, J. Oliver, and M. C. MacDowell. The collection and analysis of fluid from single nephrons of the mammalian kidney. Amer. J. Physiol. 1941, 134, 580.

10. Wearn, J. T., and A. N. Richards. Observations on the composition of glomerular urine, with particular reference to the problem of reabsorption in the renal tubules. Amer. J. Physiol. 1924, 71, 209.

11. Clapp, J. R., J. F. Watson, and R. W. Berliner. Osmolality, bicarbonate concentration, and water reabsorption in proximal tubule of the dog nephron. Amer. J. Physiol. 1963, 205, 273.

12. Soothill, J. F. Estimation of eight serum proteins by a gel diffusion precipitin technique. J. Lab. clin. Med. 1962, 59, 859.

13. Rutstein, D. D., E. F. Ingenito, and W. E. Reynolds. The determination of albumin in human blood 
plasma and serum. A method based on the interaction of albumin with an anionic dye $2-\left(4^{\prime}-\right.$ hydroxy-benzeneazo) benzoic acid. J. clin. Invest. 1954, 33, 211.

14. Baxter, J. H. Dissimilarity of changes induced in absorption spectrum of 2-(4'-hydroxyphenylazo)benzoic acid by different serum albumins. Proc. Soc. exp. Biol. (N. Y.) 1963, 113, 197.

15. Sell, S. Measurement of gamma globulin in germfree guinea pigs by hemagglutination inhibition. Proc. Soc. exp. Biol. (N. Y.) 1963, 114, 362.

16. Kabat, E. A., and M. M. Mayer. Experimental Immunochemistry, 2nd ed. Springfield, Ill., Charles C Thomas, 1961.

17. Farr, R. S. A quantitative immunochemical measure of the primary interaction between $I^{*}$ BSA and antibody. J. infect. Dis. 1958, 103, 239.

18. Ouchterlony, O. In vitro method for testing the toxin-producing capacity of diphtheria bacteria. Acta path. microbiol. scand. 1948, 25, 186.

19. Gell, P. G. H. The estimation of the individual human serum proteins by an immunological method. J. clin. Path. 1957, 10, 67.
20. Kekwick, R. A., L. Vallet, M. Cutbush, P. L. Mollison, A. R. Thomas, P. G. H. Gell, and J. F. Soothill. Estimation of gamma globulin in the serum of patients with hypogammaglobulinaemia. J. clin. Path. 1961, 14, 470.

21. Blainey, J. D., D. B. Brewer, J. Hardwicke, and J. F. Soothill. The nephrotic syndrome. Diagnosis by renal biopsy and biochemical and immunological analyses related to the response to steroid therapy. Quart. J. Med. 1960, 29, 235.

22. Rowe, D. S., and J. F. Soothill. Serum proteins in normal urine. Clin. Sci. 1961, 21, 75.

23. Rowe, D. S., and J. F. Soothill. The proteins of postural and exercise proteinuria. Clin. Sci. 1961, 21, 87.

24. Dock, W. Proteinuria and the associated renal changes. New Engl. J. Med. 1942, 227, 633.

25. Sellers, A. L., N. Griggs, J. Marmorston, and H. C. Goodman. Filtration and reabsorption of protein by the kidney. J. exp. Med. 1954, 100, 1.

26. Farquhar, M. G., S. L. Wissig, and G. E. Palade. Glomerular permeability. I. Ferritin transfer across the normal glomerular capillary wall. J. exp. Med. 1961, 113, 47. 